\title{
Battalion Command
}

\section{Colonel M. Gosset Late Dorsetshire Regiment C.B.}

To cite this article: Colonel M. Gosset Late Dorsetshire Regiment C.B. (1891)

Battalion Command, Royal United Services Institution. Journal, 35:158, 469-486, DOI: $\underline{10.1080 / 03071849109417299}$

To link to this article: http://dx.doi.org/10.1080/03071849109417299

\section{曲 Published online: 11 Sep 2009.}

Submit your article to this journal

Џ Article views: 5

Q View related articles $\sqsubset$ 
Friday, March 13, 1891.

Gexerar SIR ARTHUR J. HeRBERT, K.C.B., in tho Chair.

\section{- BATTAlion COMMIAND.}

By Colonel MI. Gosset, C.B. (late Dorsetshire Regiment).

'Tue position of the Commanding Officer of a battalion is of such importance that I feel an apology is hardly needed for my appearance at this Institution this evening, to give jou my ideas. Not that I can boast of haring anjthing novel to lay before yon, but haring now been thirty-fire years in the Service, and having lately given up tho command of a battalion, I thought that my experience might be of use to those who aspire to command, aud that I might, at any rate, open up some questions of import to our Army at the present time.

I may say, to begin with, that the command of a battalion is in these clays a mach unore difficult task than of old, simply because so mach more is demanded of all ranks than formerly. Ever since the Crimean War, wo have been slowly and, I hope, surely, advancing in a buowledge of our profession, and wo are gradunlly tcaching our joung Officers and men that soldiering means something more than a good march past and rigid morements on the barrack square. Not that I despise work in the drill ground, fur it is a part of disciplinary training which should never be relinquished, and there is a danger that in our reforms this might be lost sight of.

I will begin with the prirate soldier. In these days of talk, and a Press that is always on the look-ont for something out of which to frame a smart newsplaper article, a great deal is said and written about Tommy Athins, and many will say, and have said, that he is not the man the was.

My experience of him is that he is not the man he was-only in the sense that, as a rule, ho is a bos-but, takingr him all ro:ind, he is overy bit as good in quality, and, if treated properly, better in conduct, than of old.

So many able military men hare pointed out the danger of a boy arms, and so many regimental Officers shake their beads when they read post-prandial speeches cracking ap the efficiency of the Army in England and its readiness for service, that it is merely going orer well-trodden gronnd to allude to it.

Learing out the regiments in India, in the Mediterranean, and clsewhere out of the United Kingdom, there is not the slightest doubt 
in $m y$ mind that the majority of our home battalions are quite anfit for war, simply because they aro composed of boys.

They have not the service to have had ingrnined into their natures the value of discipline; thes have not the age and service to ensure their making the most effective use of their rifle in the excitement of action; nor have they the nge or service to enable them to withstand the hardships of a campaign, and in a fortnight half of them would be in hospital. The causes are well known:-under-age enlistment, deferred pay, which tempts a man to go at the expiration of his first period of service, and the emasculation of tho home battalion to feed the linked battalion abrond.

We Englishmen nerer seem to be able to bit off the happy mean in our reforms. Because the old soldier of trenty jears or more aro, that is, the man of from eighteen to twenty-one jear's' service, was broken down, as a rule, we mate a volte-face and put in his place a boy of sixteen or serenteen ycars of age.

I, of course, am fally sensible of tho valuo of a Rescrve, but I am at a loss to sec why a man should not be enlisted for ten or twelve sears, which would enable him to go to the Reserve at twenty-einht or thirty years of age. It appears to be the period of enlistment best suited to our voluntary Army, and would be of immense value in raising the service ralue of our battalions, and, we may also say, our Reserve.

But, boy or man, the material of our Army is excellent, and I have left my battalion- which, by the way, is now composed of men principally of an age between twenty-three and twenty-five jears-with tho highest opinion of tho British soldier. I am happily spared the pain I should feel of seeing some $300 \mathrm{~m} 400$ of them go bodily to the Reserre, and their place taken by boys.

I will now turn to how a soldier should be dealt with. So much nonsense has been written of late about the wrongs of soldiers, that the outsido world likely cnough regards him ns the most ill-used man under tho sun; that he is bullied by his Oflicers, dono in the eyo in the matter of pay, and that his life is a burden to him.

I quite allow that the question of how he should be treated with as a member of a free nation is a rerg important one. But those who write so glibly in tho papers view the matter from a civilian standpoint, and have often not the most elementary idcas of what discipline means, and how important it is, if we want to retain our old reputation in the field, that it should be maintained. There is one thing of which I am very certain, that insubordination in the Alung, wherever it exists, is not cansed by sererity, but by either a mistaken clemenc5, or else a mant of discrimination as to the degree of an offence.

I hare seen cases in which a man who cheeked a non-commissioned officer reccived the same punishment as one who orer-stayed his pass an hour or so; and what has been tho consequence? Insubordination increased, and had finally to be stamped out by the most drastic measures. You cannot rule 800 inen with rose-water. $\Delta$ nan should know beforehand what to expect if he cowmits certain offences, and it is this knowledge that either increases or diminishes crime. 
But it is not by panishment alone that men can be ruled. It is necessary for those who are not alive to any milder sort of argument; and these form a small minority in a battalion, but it is by considering the sentimental side of men's natures, and this I do not think is sufficiently thought of in dealing with men, good characters or bad. For instance, when a particular class of crime is common in a battalion, the ordinary stereotyped way of proceeding is for the Commanding Officer to issue a reginental order, conched in something like the following terms :-

"The Cornmanding Officer haring remarked that the crime of doing so-and-so has becomo rery common, he warns the battalion that any man offending in this respect in futaro will bo severely punished."

Now this is all very well, but it shows a want of knowledgo of human nature. IIistory proves that you cannot deter men from crime by threats. Arnold, of llugby, recognized this, and so did not tho authoritics at Sandhurst when I was a Cadet. Smoking was in thoso days a heinons offence-drinking was so, moro correctly. Wo wero threatened with sovero panishment, and a system of espionage was established to find us out. What happened? It was considered a fine thing to smoke and drink, and all our efforts were directed to erade the spies and to indulge ourselves with bad tobacco and worse liquor.

I am pretty certain that if the Governor liad assembled tho cadets and made it a point of honour for the good narne of the Colloge to forego these vicious habits, $I$, for one, should not have learnt to smoke at fourteen, and considered myself a very fino fellow to run threo miles to a public-liouse for the purpose of drinking rum sbrub.

And so it is with men; they should know what panishment an offence will certainly entail, but threats are bad, and return on thoso who issuo them. AIy experience is, and $I$ have never found it to fail, that by nppenling to the better feelings of men by a few chosen words on parade the evil will stop. The speaker must, of course, be believed in and have the good will of the men. If ho has not, ho has no right to be in tho position he holds.

Yet another point on the subject of punishment. A man is brought up for drunkenness or some other offence, bearing on his arm three or four good-condact badges. I think I am right in safing that tho general teudency among Commanding Offeers is to bo lenient to him because ho is so decorated. They think it will bo hard on him to take away a badge and injure him as he is leaving the Service. Now, I do not altogether agrec with the Oflicer who looked npon a number of good-conduct badges as the resnlt of a loug and successfal carcer of crime, but it is often the case that an old soldier, who knows the ropes, answers his name at tattoo and goes to bed full of drink down to the Plimsoll mark, sleeps it off, and is seldom liauled up. MIy iden on this question has always been that, if a man bears on his arm these honourable distinctions, he should be. what ho is supposed to be, and that, if not, he is a walking lie. I therefore often took avaly a badge from a man of this kind, telling him at the same time that good-conduct badges are a test of good conduct, and that, if he 
did not choose to lire up to them, I was at loss to see why I shonld deal differently with him than with any other man. Ho seldom saw it in the same light.

There is one more point in dealing with men, which is, I think, often too little thought of. Men, as a rule, are well abused if they do wrong and do not get enough credit when they do rell. Soldiers, of all otber men, are peculiarly susceptible in this respect, and, although tho ordinary Englishman is no lover of butter applied too thickly, he is keenly sensitivo to a few well-spoken words of praise. With Irish soldicrs, who are moro impressionable, and who have alwajs been difficult to manage in quarters, and are such fine fellows in war, this feeling is accentuated. Prince Kraft in one of his books mentions the case of a battalion haring failed in an attack, and who were, in consequence, broken in spirit and downlearted. Seeing this, a General Officer rodo up and siid, "Braro! You could not haro done better." The effect was magical.

It struck me jears ago how little was done to make the men acquainted with the history of their regiment.

Thero is hardly a regiment in the Serrice that has wot a glorions record to boast of, and some are exceptionally fortunate. The batta. lion I had the honour to command can boast of haring fought at Plassey under Lord Clive, at the four jears Siege of Gibraltar, in Indin, in the West Indies, and in the Peninsula, where they took part in the glorious soldiers' battle of Albuera.

To remedy this want as far as I could, I wrote out and delivered a series of lectures, taking in the wholo regimental history, illustrating the principal actions on the wall of a fres court, and showing what part the regiment took in them.

If enthusiasm is a measure of success, these lectures fulfilled their object, and by anforcing that the honour gained in so many wars could not havo been attained without good discipline, sclf-denial, ready obedience, and pluck, I do not think 1 am wrong in saying that the knowledge gained by the men of their regimental history raised their.tone, and I conld afterwards obserre a steady adrance in good conduct.

I would commend this to Commanding Officers. There is always some Officer in a battalion capable of giving lectnres of this sort, and, as an appeal to the higher feclings, they are most valuable. In fact, I would recommend for consideration whether it rould not be for the general good of the Service that the regimental history should form part of the instruction of every recruit.

It is not necessary to remind fon of tho improrement that has taken place in the soldier's condition of late years. His barracks, his food, his health, his amusements, all hare been carefully considered, and if he is not a happy man he ought to be. The danger appears to me that we may coddle him too much, and that Jeshuran may some day wax fat and kick. With all his good qualities, 'I'ommy in peacotime is a rery helpless and carcless man as regards his own good, and has in many cases to be treated like a child. He comes of a thriftless class, and, while he accepts crersthing that is done for him, he does 
bat very little for himsclf. Take the important queation of cooking, or eren the quality of his rations. The majority of tho men show a supreme indifferenco to the whole question, and tako what is giren them and say nothing, and it is only by constant supcrvision on the part of the Commanding Officer that the cooking is improved, and that the soldier is taught that it is an advantage to haro meals well cooked and served.

As regards drink, the character of the nation must cliange before we can expect it to disappear from the Army. It is not more common in the Army than among the class from which a largo proportion of our men are drawn, but a man in a red coat is nore en évidence than a civilian when labouring under the effects of liquor.

A man was brought hefore me one day for drunkenness, and he argued that it was impossible that ho could have been druvk, as he bad only taken fire pints.

But drunkenness has decreased in the Army, at least as far as my experience goes, and there is no doubt the graver forms of it can bo kept in check, such as drankenness on duty, on the line of march, \&c. I always, as a rule, panished a man more leavily for being drunk in town than in quarters, for the reason that in town he was disgracing his regiment. $\Lambda$ s many Officers know, it is not an ancommon thing when a battalion is changing quarte:s for the men to take a glass, as they call it, with their chums who are boing left bchind, and the result is scenes at a railway station highly discreditable. I Lare always found that an appeal to the men on parade, a diny or two before the move, has been quite sufficient to stop this; and, as a proof of confidence in the men, have left the canteen open till the last, and the result has been that the worst characters havo kept sober. I remember in India on an occasion of this sort, when a Captain, addressing a noterious toper, praised his sobricty. "Lor, sir," was his jubilant remark, "I ham't been so sober for jears!"

So much as regards the prirate soldier. I now more a step ligher, and deal with the non-commissioned officers.

The conduct of the non-commissioned officers and tho way they do their duty depend entirely upon the Commanding Othicer and Officers commanding companies; in short, on the sfstem of tho battalion. Raise the tono of the non-commissioned officers in erery way jou can, show that you do not intend to have one law for them and another for tho prirate, and at tho samo timo back them up, so that they are not lowered in the eyes of those nader them, and overything will generally go straight enough. The complaint, nowadays, is that the non-commissioned officers are very young, too young to properly control young soldiers just joined, and who hare not fallen into the restraints of discipline. This is unaroidable, of conrse, as long as onr present terms of enlistment remain as they are, and applies especially to the young battalions at home. Abroad, the noncommissioned officers have, as a rule, more service, and thero is not so much to complain of under that hend; at least I cau spenk from experience with my old battalion, and taking them all ronnd we had a good and intelligent lot of sergeants and corporals. There is one 
thing with referenco to non-commissioned offcers which I think in worth thinking about, and that is the question of marringe. Nowadays, no prirato soldior or corporal can marry under seren years' servicc, a wise rule enough considoring the age of the men, and the result is thero are but fer married prirates in a battalion. This, I may mention, is a drawback with reference to the washing of men's clothes, which has now often to be farmed out. But this is a minor disadrantage; what I wish to point out is that a large proportion of sergeants can,marry, and this has its effect on disciplino-I mean barracl-room discipline; and tho kecping of order in the barrackroom (and disciplino bergins thero) is often left to young corporals and lance-corporals who are afraid to excreiso their authority, the danger boing, that irregularitics are liablo to bo winked at.

With battalions of young soldiers this is a serious question, and I think it worth the consideration of the authorities whether the regulations as to the marriage of sergennts should not be arnended. I am not one of those who run dorn the non-conmissioned officors of the present dny. They are better educited than those of former dnys, and it depends in a great measure what the system of the battalion is whether they turn out well or not. Thoso who complain of them most probably think that as soon as they get the lauce stripe thoy will educate themselves, and nre astonished that they are not like ready-made clothes, fit for work at once.

As regards the Oficers, I see but little change in the class of gcutlemen who join now from those of old days. Young Officcrs who join aro generally quito ready to learn, and it depends entirely on the Conmending Officer whether they are properly taught or nut. There is no donbt, if they are not made and encouraged to study, soreral of them will let it slide. And this is quite natural. Officers are well receired whererer thes go-they hare every incitement unless properly controlled to mako their duty subserrient to their pleasures, and it is very much to the credit of our Oficers that they bare, as a rule, a strong seuse of duty. The manner in which this sense is fostered and applied depends on the Commauding Oflicer and on the Captrins of companies.

. In old days, as all men of any servico will well remember, the whole business of a regiment was in the hands of the Commanding Officer and tho Adjatant-the Captains werc nowhere. They had no encourngement to act on their own responsibility, and the cousequence was that they looked to the Commnnding Onicer for everything. Somo men are so constituted that they will accept responsibility in all circumstances, but many are not, and $I$ and certain that if a Commanding Officer wants his battalion to be in good order, he must insist ou everyone doing his own work and not look to nnyone clso to do it for him. $\Delta$ Commanding Officer's and $\Delta$ djutant's battalion is bad. A Commanding Officer should not be like the Minister in the "Mrikado," a man holding a plurality of offices, but should act on the principle of "Divide and govern."

I lave alwajs regarded this principle of decentralization as ono of. the most. important questions relating to command, and in carrying. 
it out have found that Captains of companies : soon learn to take a higher view of their dutics, and by acecpting responsibility thomselves have exacted a proper share from those under them. There is no doult that Officers not so trained are apt when they get command of a battalion to be always referring questions to the General in command which they ought to settle themselves, and there is often a tevdency anzong General Officers to encourage this instead of refusing to interfere. The same way be said with reference to work in the field. If cnough latitude is not given to Oflicers commanding companies, and they ard always interfered with, they won't act independently, and I have seen many a well-conceired little mancuvro fall through from want of initintive on the part of junior Officers; and who bas not seen a Commanding Officer wake bis battalion look foolish by want of this sense of responsibility and an appreciation of the situation on a field das?

I lope I may be excused criticizing Offeces of a rank higher than my own, but the fault in our rewimental training of a Commanding Ofticer resting everything in himself, and not giving cnough responsibility to subordinates, has often been the cause of undue interferenco with battalions both in quarters and the field-rith the result that a sensitire Commonding Offeer is apt to bo in a perpetual state of irritation, and a nerrous one to tremble when he sees a cocked hat, and to be almost servile to an A.D.C.

Tho regulations of lnte years as to company training, musketry, \&c., all tend to train all ranks to accepting responsibility with good results, but I fear there aro still somo Commanding Officers who cannot resist the temptation of trying to do ererything thomsolves. They may hare their battalion in capital order, but they do not leave enongh behind them, and there is always a darger of the whole fabric falling to pieces.

At the same time, the Commanding Officer of a battalion is the life and soul of it -he must hare his eje on evergthing, know erergone's wants, and neror imagine, because ho has established a good system, that it will keep going withont a perpetual greasing of the wheels. I excused mysulf somo time ago from attending somo cntortainment, by saying I had work to do; a lady at onco said, "A Commanding Oflicer has nothing to do: be has only to issue orders." This is the popular idea, no donbt, and it is as easy to issue an order as it is to write out a cheque; but it may not always be cashed. Our friend JIr. Pecksniff remarked: "If Fngland expects every man to do his duty, she is rery much mistaken ;" and he showed his knowledgo of mankind. 'There is always somebody who wants gentle persuasion or otherwise to do his duty, and orders, however sensible, oiten fall through from want of the superrision uecessars to bave them properly carried out. I think it was Lieutenant iray, of the German Arrns, writing of the War of 1870-71, who pointed out that tho men composing an attacking force were to be divided into three classes. The first class rrere tho brarest and best-who led the way.; the second those that only wanted a lead to go on; and the third thoso who had alwajs an ego over their slioulder with a.view to going back: So it 
is in the matter of duty, and it is the third category who hare to be spurred on.

Haring dealt generally with the rarious ranks that make up a bat. talion, I will go on to the important subject of cducation. After I began to write this paper, I came ncross a lecture delivered in this Institution last year by Major Ker Fox, on the Training of Cavalry ; and in the discussion that followed, General Sir Charles Shute, who presided, alluded in forcible terms to the system in our Ariny of detaching Officers from their battalions for acquiring knowledge.

I do not myself see how this is to be entirely aroided until we have advanced considerably in knowledge; but $I$ hare long been of opinion that the regiment or battalion should be the schonl of in. struction for all ranks. I do not mean to say that every Commanding Officer or every Captain is capable of becoming a good iustructor'; but there is generally in a battalion some Officer who has the knowledge and aptitade for the work : and anjone who has instracted Officers or men will tell fou that he himself learns as he instructs. If wo waut to makc a real advance, the battalion must become its or'n school, and the schooling should be gradual from the time an Officer or man enters tho Service. Thero may be some who think that the time bas not arrived for this reform. Judging from m5 own experience I think it has, and I should hail with pleasnre when the orcier is issued to do away with garrison instructions und adopt regimental instraction in their place. It is a melancholy thought, that in order to cnable an Oflicer to pass for promotion to a higher grade it should bo necessary to detach him from his battalion to go through a system of cram. I know of nothing more calculated to disgust an Ufficer with subjects with which hit should be well acquainted. Nowadays, many Officers commauding battalions are S.C. men, and could easily direct the instruction of all ranks theoretically and practically.

There are, of course, great drawbacks in the matter of practical instruction in tactics, \&c., in hot climates during a considerable portion of the Jear; but we might carry out a great deal nore instruction, and more particularly of the Oliticers and non-commissioned officers, than wo do now.

I would commend to the notice of Commanding Oficers tho interchangeable war-game maps of Lieutenant Sharpe, 3rd Mlicullesex Il.V. I had them in use for three jears, and, cluring tho summer months in Malta and Fgypt, worked out small schemes, which brought in map-reading, the issue of orders, the working of reconuoitring and strong patrols, and outpost work. Both Offcers and non-commissioned officers took much interest in these schemes, and no donbt a good deal of knowledge was gained; while, as a preparation for the aunual company training, it is useful.

As regards non-commissioned officers, tho more jou can educate them in the practical part of their profession the better : and that this is recognized is shown by the recent orders as regards their examination for promotion, and placing the preparations for these examinations in the hands of the Captains. This and the company training, 
honestly and intelligently carricd ont, ought to advance them con: siderably in knowledge. The tendency is for non-commissioned officers (as also in tho case of Oficers) to get a parrot-like knowledge of the book, and to be utterly abroad in the field. Many of them, when lance-corporals, show great intelligence; but often promotion secms to dwarf their intellect. Whether this is the result of the narrowing tendency of barrnck rontine $I$ do not know: but it is the case, and $I$ hare often been surprised by the utter absence of "nous" and intelligence (on the ground) shown by good men. Company training has done a great deal to ituprove our non-commissioned officers, nnd, as time goes on, we shall get much better work out of them.

As regards the annual training of companies, I latterly had two companies training at the same time, in order that a good deal of the tactical rork conld be carricd out with opposing forces under some special idea, and so made as liko as possible to what would really happen on serrice. The varied ground roand Cairo is particularly suited for minor tactics, and mach interest was shown by all ranks in the work, sinply becauso they lad vers little to imagine.

To tell Tommy Atkins that a certain position is occupied by an enemy when it is not, conveys but little to his mind; but let him seo somo helmets showing orer a trench, or a wreath of smoke, and the report of a rifle, and he realizes the situation at once. It, of course, depends on the quarter a battalion happens to be in whether there are facilities for practical tactics; but I know from experience that, if a Commanding Officer will take the trouble to risit the farmers in England, they will, as a rale, allow troops to manœurro ovor their land, and will turn out with their families to see.

With regard to the prisate soldiers, I mas be thought somewhat of a heretic when I say that the tendency nowadays is not to teach him too little, but too much; or rather, I might sas, that we aro apt to lose sight of certain cssentials which wake the good serrice soldier, while we stuff him with a good deal that may well be left alone.

No one is more convinced of the ralue of the annual training of men by their own Offecrs than I am, and I have always taken a great interest in it, and have striven to make it as practical as possiblo; but, as far as the privato is concerned, I would use the shears and cut dorrn a good denl of it. Four weeks is too long to keep men at instruction, they weary of it; aud, moreover, it is only in England where we can afford to gire so much time. In hot climates, where all the practical instruction of a battalion has to be carried out during a period of six months or less, the course has to bo curtailed, and $\mathbf{I}$ have found that fourteen days of good, steady, practical work is very nearly, if not quite, enough for a company.

The Qucen's Regalations lay down that, when practicable, infantry should go throngh a short course of instruction in field works, which includes modelling, indoor tracing, making siege parallels, field redoubts, \&c. It is impossible to gire Tommy Atkins anything bat the most rudimentary knowledge of all this; and it has often made me sad to see him patting the superior slope of a model fort which has been traced out and mado withont any governing tactical idea, 
and in a position where no one on service would place a fort. Teach Oticers and non-commissioned officers how to do these things, if you like, but let Tommy Atkins be taught simply how to dig without breaking the handles of his pick and shorel.

I have said abore that wo aro apt to lose sight of certain essentials in our strivings to make 'lommy a Jack-of-all-trades. Theso essen. tials are-1st: Discipline. 2nd. The power of marching long distances well. 3rd. Tho power of shooting well.

1. No military man requires to be reminded of the Falue of disci. pline. It is the first thing and crerything, for without it jou can do nothing. I haro alreads alluded to it, and I would ndl that it can be fostered best by inculeating a feeling of honour throughout every rank, and a sentiment that it is the duty of erery individual to strire to maintain the good name of the corps.

2. As regards marching. Good marching means that men are able to stand hard work, and get alongside an enemy in good form.

Our physical training has always, as a rule, tended more to strengthen a man's arms than his legs, whereas the latter are more important of the two, for it is the soldier's power of morement that is everything in war. This porrer is not to be gained by a routo march once a week. As far as my experience goes, the onls way to attain it is to have running drill extending orer some months. During my command, I had running drill erery morning for thrco or fonr months in the winter, beginning with short distances, until the men could get over 1,000 or 1,200 jards, carrsing their rilles without distress. It is tho only was to make men march woll, and also to make their boots ensy. A man's boot gets into shapo in the action of running; and if they are bept soft by dubbing-a pot of which I made part of the soldier's kit-they can do anything. In Egypt, where we had long field days in the desert, somo miles from the barracks, I found that the men could do a long day's work, and come home singing at the cud at a swinging pace.

As regards the third attainnent, "shooting," a great deal has been written and said. Good shooting at a target is not difficult to attain; and it steadily improres as the men grow older. All that is wanted is that all ranks, beginuing with the Commanding Officer, should take the interest in it that so important a part of a soldier's training deserres. When once the spirit is infused into a battalion, erery man does his best, and the older the soldier the better he shoots, as a rulc, provided he does not suffer from any visnal defect. T'his is an argitment in fivour of older soldicrs. Ask Offecrs who hare commanded companies of young men duriug some of our small wars, and they will tell you of many cases of wild and useless firing: Instraction in tho uso of the rifle should not ccase with the annnal course, but should always bo going on. I made it a rule nerer to hare a battalion parade without firing rolleys'by sections, always directing the ain at some point, generally oblique to the front of the line. As a lesson in fire discipline, and in teaching Officers and non-commissioned officers to give good words of cummand, aud to attend to tho adjustment of the sights, \&c., it was rery uscful, and the result was 
that, eren if the individual firing during the annual course was not so good as it might hare been, tho rolles firing, both ordicary and rapid, was very good.

I do not think the practice of volley firing on parade can bo carried too far, as it accustoms the hand and ejo to work together, and in wartime men so trained would probably wait for the word of command from pure habit; and, with vers young soldicrs such as composo so many of our battalions, the cxcreise is absolntely necessary.

There is one question with reference to individual shooting which might, in my opinion, yoll be seriously considered. It is, that crery company has a fow nen who, either from defectiro sight, stapidity, or any other cause, remain 3rd-class shots all their serrice. Notwithstanding this they go through the samo course as tho rest of the company. If a man cannot make a decent score up to 400 yards, it scerss absurd to allow him to fire at the longer distances. Ho should be made to fire at the short distances antil ho gains something liko a deccnt score.

A 3rd-class shot is an ineffectire soldier, and one very good regalation is not to allow men of this class to hold any position such as an Officer's servant, mess waiter, canteen waiter, \&c., or to be put on any other regiment or garrison emplos, until they get out of the 3rd class. I found it had the effect of making bad shots tako pains and improre, simply because ther got extra parades, and their comrades ridiculed them. It also gare marksmen and lst-class shots n higher sense of their position in the battalion.

I think also that we do not, as a 2ule, consider suficiently tho ralne of the field practices: 'I'hey aro the test of what a company is worth indiridually and collectirely, and I should like to seo more stress laid on thcir importance.

As regards battalions making rers high scores in tho individunl practices, I am a Eceptic. There is likely to be a tendener to maintain the position of being a good shooting battalion by hook or by crook. I do not know which are the battalions on the top of the list, so I am not casting any aspersions, but I am surc, in my own. miud, that while it is possible for a battalion of old soldicrs to hold a high place; it is not possible for them to retain it when 200 or 300 of them go to the Reserve, and their place is filled by boys. It can be regained of course if the instruction and the spirit of the men is good, but only gradualls.

With the introduction of the new rife, our shooting onglat to improve, for there is no doult that one cause of bad shooting with tho Mrartini-Henry is the kick:

I hare seen men at bathing parades with their shoulders black and blue, and thero aro many men who haro to put a pad to their shonlders to obviate it. It will be said that this is the result of bad position in firing. I do not think so ; for I know many first-rato shots, Officers and nen, who saffer in this way. It depends on their build.

I hare often thought that, supposing you gare a man 100 rounds before startivg to attack a position, he would hardly be able to pat 
the Henrs-Arartini to his shoulder at all when ho reached tho effective distances, and when indepondent firing began, would most likely fire from his hip.

As a rider to the question of the instruction of men, I rould mention that last suminer I found mysclf in a railway carriage with a serjeant, and, in answer to certain questions I put to him with reference to the recruiting of his battalion, he said, "Onr three-yenrs mon are now so bothered with drill, training, and perpetual workthat it has the worst effect upon recruiting. They long for the day when they can take their discharge, and they go to their villages carrying with them a feeling of disgust for the Service."

This shows that with our rolantary Army, particularly with men who cnlist for so short a term as three years, wo may debar men from joining the ranks from trop de zêle.

It was Sir Cornewall Lewis who said that men in theso dags do a great deal too mach, and I think the tendency is, with regard to the private, to try and grow corn on uncultured ground. Educate the Officers and non-commissioned officers as high as you can, especiall at a time when their minds are most receptive, but go judiciously with 'lommy, who is apt to ask why ho is being humbugged about, and to resent it.

In bringing what I havo to say to a conclusion, I should like to add one or two general remarks.

In the first place, I would say that, while our Army has made great strides in many wajs, $I$, as a regimental Officer, have never been able thoroughly to fall in with some of the changes in the last two decades. Tho old regimental system had its faults, and as a matter of policy with reference to recruiting, the linking of battalions may have been necessary, but it has its bad side in creating a fecling of unrest, and in loosening the old ties of camaraderie that existed in old days between Officers aud men. This has been increased by the short service sfstem, by the frequent changes among Officers caused by transfer on promotion, by the method of officering the Indinn Staff Corps, \&c. In fact, in our Servico we aro always rolbbing Peter to pay Paul. I do not say that in sach a complex system as ours it is to be altogether. avoided, but the perpetual change that goes on affects the Army injuriously, and, moreorer, touches up the pocket of the taxpayer.

The only adrantago it seems to mo to possess is that it infuses new blood in a battalion, and even that is not always wanted. I hope the day is not far distant when regimental numbers will be restored. It requires a man of more than ordinary intellect to remember the long titles now in use, and for war they are absolutely impracticable. I beliere the clerks in the War Office have still, after ten sears, to put the old numbers opposite the titles in their books, in order to aroid mistakes, and as for the ontside world, titles aro all ranity and vexation of spirit.

Another reform I should hail with plessure is that when an Officer has completed his period of Staff service, the regulation with reference to his going back to regimental work shonld be rigidly 
enforced. Nothing does a battalion more good, if ho is a good soldier, and does not look on regimental work as infra dig., and as. regards himself, he learns an immenso deal which is of the greatest use to him and the Army when he reverts again to Staff duties. Officers who pass the greater part of their servico on the Staff lose their touch with the soldier, do not know what he is capable of, and when they" get to high commands mny have to learn at his cxpense. I would also suggest that Officor's who go to the Staff Collego should be seconded; and when they havo finished their courses should always return to regimental life for a season as supernumeraries. Without it they cannot kcep abrcast of the work. It would bo of advantage to them, and, as regards a battalion, it is hard to doprivo it in these days of such an important Officer as a Captain for $2 \frac{1}{2}$ years without filling up his place.

I am conscious that thero is much that $I$ havo stated which is already met by tho regulations of the Serrice, and have becn dealt with by abler men thnin myself. All I hopo is that the princtical experience of a Commanding Officer in carrying out tho regulations may be of some value.

Iicutenant-Colonel $\mathrm{D}_{E}$ Bersireze (Worcester Regiment): It is with some diffidence $I$ speak on this subject, but haring had the honour of cornutuding a battalion now. for eome eightecn months, I should like to thank the lecturer very much for his most interesting and very instructiro lecture. I agree cntirely with, what he has eaid with respect to the discipline of a battalion; par. ticularly with regard to the punishment of the men, so that when an offender comes before his Commanding Oflicer he mas almost be able to punish himself, that is to say, he knows exactly how his particular offence is inrariably dealt with.' dgain, as to good-conduct men, I always try to impress on my men, that an offender coming before me, and bearing on his arm a good-conduct badge, must not think for a moment that he can trade on his record, or that he can possibly expect to be let off becanse he has it. I think tho men thoroughly understand now that good-conduct badges should mean influenec and example in the buttalion. I wust eay that I should liko to hare my recruits sent to me straight on enlist ment. Brigade depóts are raluable as recruiting ccutres, but the recruit should come at once to his future Commanding Officer to be improred physically and trained professionally. I try to get my men well seasoned after I receire them; to feed them well, work them well, and teach them the use of their limbs. As one means to this end, I hare started a coffec shop in my barracks, and I hare found it a most useful inetitution, insomuch that the young soldicr feels contented and comfortable when he finds in his barracks what formerly could only be got outside. To accomplish this end also, there is a credit system, and a man can hare a pint of beer with his supper, if he so rishes. The Commander of the Fosces in Ircland, risiting us at Iinerick last Norember, expressed approral of the coffee shop arrangements. With regard to nou-cominissioned oflicers, I must say I am entisfied with minc. IBesides $\mathrm{my}$ sergeants' mess I hare a corporals' room, which I find answers very well indeed-not a corporals' mess, but simply a room. It gires the corporals a status and position in the regiment ; thes, of course, dine in the barrack room, but this gives them a room for themselres whero thes can read and work. The lecturce spoke of the chain of responsibility, the responsibility not being on une man's eloulders, but going through the battalions from the tip to the bottom; each one knowing that, whaterer department or show ho has to run, he is entirely responsible for it to the Commanding Oficer. I am sure we shall all adnit that this inculcatcs sclf-reliance, judgment, and common sense; and junior Oficers are thus dails being trained for command, by acting independently, and not referring erers single thing. Again, as to the mancurres that tho lecturer spoke about and the cirility YOL. XXXY. $2 \mathrm{x}$ 
of furmers, I must say that the furmers in our part of the country round Linerick are, as a rule, most considerate. We alkays go out once a weck, caralry, artillery, and infuntry, und hare some tactical exurcises. The farmers arc rery ciril and allow us to go orer their ground, and manourro about in erery possible way. Theso mancurres are crersthing for the men; they improre their indiridual in. telligence, and keenness and interest aro plain all round. Young soldiers go out at cight, or lialf-past, como back at two or thrce, and not a mun falls out, for the interest carrics thein through, the interest which would be wanting in the ordinary route march. I alwags try to impress upon erery one that, from the Commanding Odicer to tho youngest recruit and smallest drummer boj, whero all mect on one platform, cach one is feeling that on me depends the good name, tho practical eficienc5, and smartnes 3 of the battalion. 'This fulls realized all round, then jou lare the ideal regiment.

Lieut.-Colonel WV. T. Dooxrn (Rl. Inniskilling Fus.) : MIr. Chairman, ladies and gentlemen, I only rise to say how thoroughly I agreo with almost ererything that Colonel Gosset las eaid in his rers execllent lecture. I think thero cannot be two opinions as to whether it is better to try and rulo men by appealing to their sentiments ; by speaking to them of their country, their patriotism, their regiment, call it what you will, than to endearour to rule them by either threats or punishment. I quite agree with what Colonel Gossct has said on that point. I fear the regulated time allotted to each speaker would run out if I were to mention all tho subjects which he has alluded to and on which we are all probably of one opinion; I will, there. fore, go at once to one or two little points, not for a moment to differ with him, but to mention that, ns lie his commanded a battalion abroad, and as I lisre tho bonour of commanding a battalion at home, all the suggestions he has marle aro not sometimes practicable on home ecrrice. Tuke, for instance, what has been said with regard to garrison instruction and doing away with it. I quito agros with what Colonel Gosset has said, but let me tell you what ny experience was. I started a system of instruction tho mowent I could, in order to prorent, if possible, the Oflicers of my battalion haring to go away to thosc classes of instruction, and also because I quito anree with the lecturer that it is more or less a reflection on Commanding Officers if those under them have to go elsewhere to learn their pro. fession. I thercfore started classes trice a reck, and my lope was that I should hare been ablo to make the whole of the Oficcrs go up for examination together; I found, howerer, after I had got through one subject with the greatest difliculty, that I had to gire up my idea in despair. The Offecrs that I could catch one day I could not catch tho next. What with District Court.3Iartials, with boards, and all garrison duties that they had to perform, thcy were taken awas from my instruction, and $I$ was going over and orer the subject, and at last $I$ had to gire it up. There is also another point with regard to that garrison instruction which should be mentioned; I think it would be, perhips, a little hard to expect ereryone, I mean all Commanding Oflscers, to be quito prepared to answer all the questione which are giren, until the examinations become a little moro practical, For in. etance, an Oflicer rushed into mo gome timo ago after an eramination had taken place, saying, "Ol, tell me, hare I made a mistake in this question?" "The ques. tion was to drow the scale of a bilometro to a deciroctrc. Now, I think thero is no use when you come to think of it, in asking any Oficer such as question as that: because, when could they crer possibly be required to drin the scile of a kilometre to a decjmetre? We know the French, when thes make a map or plan, alwajs put the representative fraction on it, and that question was put, I fear, in order, more or less, to mako tho Oflicers in the luurry of an examination get nerrous and be. wildered. In anotler examination, the question ras asked, "Comparative to one inch to a mile, draw a scalc of Russian rersts." Now, if the Crimea were to come orer again, of course we all know we would try and get inaps of the country we were fighting in, in erery pQssible way; we mould go into the first houses wo came to until we succeded in getting one; and haring got it, wo know perfectly well, in the country in question maps will not haro their scales expresed in that peculiar way; they will have the representatire fraction giren; I only mention thoso two questions which occur to me just to show the lecturer that there aro considerable dificulties in attempting to carry out all the instructions that would be necessary 
to enable Offecrs to pass their examinations. Thero is one thing Colonel Gosact atutes in which I difier a little, und I rcjoice that I get the opportunity here of meationing it. Io sass that Irislımen are vers impressionable. I quite ugree with him that they are; but then, when he sass that they are alwajs more difficult to manage in quarters than other people, in wy opinion there is a mistake there; I bnow it is the opinion all through tho $\Delta$ rmy, but I think there is a little crror in it. In Irishmin, take him on the points that the lecturer mentions, bis country or Jis reginent, \&c., and there is no man more ready or moro milling to keep up the credit of both; that is what my experience has been. I find what Colonel Gossct eays, namely, mentioning on parade afew things like that has a most wonderful effect; and as for sererity of punishment and threats, cxcept in the worst cascz, ns Colonel Gosset sajs, they are better aroidcd. There is one subject that has not been dealt with bs the lecturer, riz., the question of bad characters, and rhat is best to do with them. I think that Commanding Officers, and I hope there are mang such Officers here, ought to make up their ninds that they will not discharge any man as cither incorrigible or worthless, or with disgrace, I mas call it, unlcss there is some very serious cause for so doing. I think that by discharging these men re only pass them on to other reginents. The State will uot allow us to mark the mon in nny way, so as to prerent their re-enlisting; and I think if all Commanding Offecrs were to make up their zoinds that thes would not discharge ans of these men, if thej hiad the bad luck to get one or tro, until tho men in question had at least serred fire or six jears, and, therefore, mould not be able to cnlist again, it would be rery adrantagcous: becausc any approsing Oficer, when a man has had fre or six sears' eerrice, will probably be ablo to spot bien as haring pretiously ecreed in the Army. If he is a young fellow who has previously serred who tries to enlist, these men come in such a $7 a 5$, dressed in old clotlics, and they imitate cirilians of that class of life eo well, that l myself, haring colisted hundreds of men in the last two years, knom of two cases in which I lase been tnken in, that is, that the men had ecrred before. I take the greatest trouble, but still I hare been done in that waJ; it is most diffeult to be ccrtnin on this point of men lisring prcriously serred. At Portsmouth there is a custom that we Commanding Oficers hare to take what they call the details for three month 3 in turn, and 80 the recruits enlisted for all the regiments round ubout pass through our hands during the time mentioned. I therefore liare had some little cxperience of this qucstion of enlistment, and I know that in two cases; probably there were more, I have been, so to speak, done by these bad characters. Frers ship that comes home from India brings eome cighteen or twenty of these men. Thes ure brought up suddenly into your guard room, and they are all then turned adrift into this country to do the greatcst barm to the Serrice, and also to find themselres. I fear, shortly afterwards in some regiment. I therefore think that if we diu not discharge these nien until thes were a little older and hare more deferred pay to lose, it would be better. With regard to what Colonel Gosset said about the wilitary training, there cannot, I think, be two opinions. It is a great deal too long, and the annoying part of it is that actually the Commanding Officer is not considered, I suppose, capable or uble to instruct his regiment, and he has the plensure of eceing his companies going out, and almost losing in somc cases four recks of their raluable time-the summer is not vers. long - two companies are.taken anas from him the whole summer, one for musketry, and one for this military training. If you take the state of any regiment and inrestigate it, you will find a Conmanding Onicer is not then left with moro than 100 or 120 men for the duties; and thus I go on parade, and hare to content mysclf with drilling come four companies of perlaps fourteen or fifteen files in single rank. I hope that point that the lecturer ling brought to our notice rill be well thought about and considered by those in authority, bceausc I quite agree with him that the men do not like it. Thes tire of it, thes do not care for being what thes call "humbugged about," and it is a littlo hard on the Commanding Officers. I do not know whether Colonel Gosset found it so in Egspt, and whether he was nble to get more men in his battalion than $1 \mathrm{am}$, but the consequence of the present regulation is, that the nen are taken away from us during the whole sunmer, and the Commanding Oficer is unable to carry out much raluable inetruction and work that he rould perhaps wish to inaugurate and accoinplisl. 
Colonel M. Gosser, C.B. : With reference to the remarks made by Colonel De Berniere and Colonel Dooner, it is a grcat pleusure to me to find that they agree with me in the main points in my paper. There are one or two questions which thes have alluded to which I think are important. Colonel De Bernicre spoke nbout the corporals' room. Two or tlirec years ago there was an order issued to cstablish corporals' messes, Thich meant to say that jou took the corporals aray from the barrack rooms for their incals. I, for one, opposed that strongly, becuuse you want men of authority in the barrack rooms. The ecrgeants' mess naturally takes the sergeants away, and if you hare a corporals' mess, which includes lancecorporals, the mgn's rooms are left cutirely without anjbody of anj position to overlook them. I do not think we hare reached that adranced stage of culture which will allow us to deprire the barrack rooms of the corporals. But a corporals room, if properls carried out, raiscs the status of the corporil and gires him a more elevated idea of his position. MIy object wus to prerent the corporals and men drinking together, and I made my corporals' room as comfortable as I possibly could. They had their music and dance meetings, \&e., and it is no doubt a rers excellent institution in a batfalion. There is a great deal, I quite allow, in wliat Colonel Dooner eaid as to my idea of doing away with garrison instruction. That is a question which $I$, of course, judge according to what I liare secn in my own surroundings, and, haring been abroad some tiwe, I may not be able to deal witli the jnatter from erery point of riew, but, judging from $\mathrm{mJ}_{\mathrm{j}}$ own corps and from what I have ecen, I think that by gradually inst ructing the Oflicers as they join and establishing a school in the regiment, the necesary instruction which would enable an Oficer to pass for his promotion may be got through. I hare not eaid so in my lecture, but what I really had in my mind was that, when musketry assumed such an -important position in the British $A$ rmy as it did after the Crimean War, musketry instructors were appointed. After a time, it was found that they could be done away with, und they rery properly were done away with. Now, I think if it is not found that you can instruct the regiment at present (and I think it is quite mssible you could not, for the reasons giren by Colonel Dooncr), in the way which I should like to ece done-why not lare a reginental instructor just in the same way as you had the old mushetsy instrucior? As I say, a man leurng as he instructs, and it would not be a rers costly appointment. I do think that rou might prepare Officers for their eranination in the battalion. The regimental instructor would be under the Conmanding Officer and controlled by him, and under well-considered regulations, I think it would be a decided adrantage. I confess, myself, I could not answer a good many of the eramination questions that are put to Officers who have gone through a course of garrison instruction, and if they bronght to me such conundrums as thes did to Colonel Dooner-I am glad to say that nobody erer consulted me to that extent-I should hare shied at them as Ite did. Colonel Dooner has the lonour of being an lrishman, and, therefore, I liope be has not taken any offence at the remarks that I hare made about his countrrmen. I3ut I always had an idea from eccing Irisl regiments that they ure very impressionable and vers much open to sentinent, and, ns a rule, diflicult to manage in quarters. I think it is the rers iropressionability which males the diuficulty, and what $I$ wanted to point out is that they are more open to a good word than anybody else. The fault an Finglishuman ofien commits when he is comsnanding Irishinen is that he is too dosnright with them, and does not take eufficientls into account the ecntimental side of their nature. One important question has been raised as to the discharge of bad characters, and I must say I do not agree with Colonel 1)ooner in what he has said on the subject. For many years, as most of us who are old soldiers remember, the Horse Guards fought against

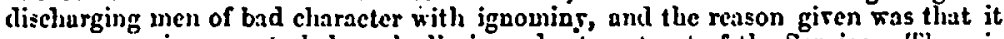
was encouraging men to behave badly in order to get out of the Serrice. There is a good deal in that argument, but I must eas the clinge that has come orer us of late yeurs, in allowing an Oficer commanding a battalion to recommend bad charateters to be discliarged, is a good move; I alrags excreised it to the full, and beliered in it thoroughly. Colonel Dooner's argument appears to be this, that the men merely go out of one reginent to get into another. I daresay he is perfectly right in some cases IIe suggests that they should remain fire or six years in the regiment, and 
that there would then be less chance of their re-cnlieting. Nor, what is the use of allowing a man of excessirely bad character to erert a bad infuence in a battalion; arconget a lot of bojs, for fire or six Jears?

Colonel Dooxes : I did not refer to men of excessirely bad character.

Colonel Gosser: I cannot help thinking the rule nor is a good one, and I should be rery sorry to see it curtailed in any way. I I think it should be left to the Commanding Otilicer entirely to judge the question himeelf. Without doubt it is a bad thing for the young men who join to have alongeide them scoundrols who will nerer inake good soldiers and wlio epend the begt part of their serrice as defaulters or in prison., It is better to get rid of them and hare dono with them altogether.

The Crisurax : Oentlemen, I think that I hare seldom heard a lecture with which I could find so little to caril. There is scarcely a sentence with wlich I do not agrce. In fact, amongst those who hare epoken, there are only somo rery trifling differences of opinion. The points referred to are discharges with ignoming; the Irish; and garrison classes. Now, with regard to Irishmen, Fnglielimen, and Scotclimen, there is no doubt that they require to be treated in different ways. I remember, many Jears ngo, when I was a young man, my Commanding Onlicer instructing me in my dutics, when $I$ was going on detachment, said, "Treat nen of rarious nationalities in different ways. Let an Irishman talk as much as he likes, let him stand up before jou, and eas.whaterer lie likes, then give him his punishment, and be will say, 'Thank your honour.' With a Scotchmon, girc him the law; read to him the Articles of War, the regulations, and he will be perfectly eatisficd. With an Englishman, on the contrary, gire him his punishment and say nothing." That was the adrice which was giren to me, and it was one which I followed, and I found it, geuerally speaking, successful. With regard to discharges with ignoming, I agree with Colonel Gosset that it is a great pity to keep a bad character in a. regiment; he is sure to corrupt the young soldiers and lead them astray. If you turn him out, he may enlist in another regiment, and they will soon find him out, and get rid of him. Men do not now like being turned out of a regiment, as thes lose their deferred pay. In former days, when the authorities made great objections to men being turned out of regiments, they did not lose any pay, and they did not mind it. Therefore, I think the authoritics are quito right in authorizing the Commanding Officers to rat rid of bad cliaracters ; in fact, $I$ would let them turn out any man whom thes could not managc. With regard to garrison clisses, I think a modified scheme might be brouglut about, so as to aroid so manj Officers being absent at garrison classes. If there were a Board of Com. manding Officers assembled in a garrison, and they ect tho questions to the candidates, the Oflicers could be cducated in their regiments; but if the questions be set by persons who hare not always pructical knowledge, the questions become too theorctical, and to be able to answer correctly, Onicers must atteud garrison classes. There is one point on which I do not agree with Colonel Gosset, but on this point the majority of the audience was eridently quite in accord with the lecturer, as directly he eaid, "Let ns return to our old numbers," creryone applauded. Will ans one get up and be good enough to state how it is to be done? Kegiments were linked, thes were joined together; one was called the 52nd, the other the $13 \mathrm{rd}$. Was a man to change his number erery time the changed his battalion; was a man, when he is transferred, to cliange his uniform as he did formerly? I was on the Coumittec that recommended the change, and though I disliked it uncommonly, still as long as linked regiments continued, as long as the same principle of organization which existed was maintained, I do not see how the change could be aroided. It has been proposed, and in my opinion the plan would answer, e.g., to re-number the regiments, giring botll battalions the numbers of the regimentul clepots. That mould simplify the question, but I am afraid that would not be popular, because, for instance, battalions whose numbers were changed would grumble, the 52nd would not like to be called the 2nd Hatt. 43rd.

Colonel Dooxen: I beliere there would be rery few objectiong.

Colonel Gosser : IIs idea was that you should not revert to jour old numbers, but that it should be the Brigade Depust number. From a practical point of riew Jou would want a number in place of a title. 
The Crarnysx: In that I perfectly agrec. I know the difficulty of long titles. Now, gentlemen, I think jou will all agree with me in thanking Colonel Gosset for the most instructire and most interesting lecture that I liare leard for a long time. It is practical to the end, and there is ecarcely a eentence in it with which anjone can disagree. I beg to return Colonel Gosset our rery best thanks.

General Lord Cnemssford, G.C.B.: Will rou allow me a few words, to say how rers much I regret that I was prerented by public business from presiding on this occasion? Mfy feclings are very much reliered by finding that ny place has been so much better taken than I should hare done it myself, by wy friend Sir Arthur Herbert. At the eame time I may saj that this is a subject in which I take the decpest interest. I am not going to discuss the lecture at all, but I read it, and read it carefully, and I cndorso erery single word that Sir Arthur Herbert has said about the great ralue of that lecture. 